\title{
EVALUATING AN AUTOMATED OBJECT-ORIENTED METHOD TO DELINEATE DRUMLINS FROM BOTH TERRESTRIAL AND SUBMARINE DIGITAL ELEVATION MODELS
}

\author{
Kakoli Saha ${ }^{1 *}$, Katrien J. J. Van Landeghem ${ }^{2}$ \\ ${ }^{1}$ Department of Planning, School of planning and Architecture, Bhopal, Bhopal, 462030, India- \\ kakolisaha@spabhopal.ac.in \\ ${ }^{2}$ School of Ocean Sciences, Bangor University, Menai Bridge, LL59 5AB, UK- \\ k.v.landeghem@bangor.ac.uk
}

Commission: TCIII-Remote Sensing

KEY WORDS: Object-oriented classification, Drumlins, eCognition Developer

\begin{abstract}
:
In the field of geomorphological mapping, the demand for automated delineation of bedforms is growing due to the increasing availability of Digital Elevation Models (DEMs) in small to medium resolutions. This automated technique is not commonly applied in submarine DEMs, where bedform morphology is often subdued due to erosion and part-burial. Here we analyse drumlins in both terrestrial and submarine environments to compare and contrast the set of rules needed for their automated delineation from 3D topographic data. An existing set of rules for automated extraction to delineate the perimeter of terrestrial drumlins was developed in 2011 using object-oriented classification tools, available through eCognition Developer (V.8.7.2). This partly supervised method is evaluated here and subsequently adjusted to be applied to extract drumlins from a submarine DEM with a higher resolution. Several adjustments were needed due to the morphologic differences between the terrestrial and the submarine drumlins. For submarine drumlins, a focus on variation in elevation in the tool is needed, as part-burial and overprinting by other bedforms is common in submarine settings. A Canny Edge Detector filter was used instead of the Sobel Edge detection filter, whilst slope gradient and direction played a larger role in the set of rules. Visual and quantitative comparison with manually delineated drumlin perimeters confirms the success of this revised automated extraction method in both terrestrial and submarine environments. The flexibility and precision of this method thus allow for the future development of object-oriented classification tools to delineate a wide range of bedforms from large-scale DEMs collected from all environments.
\end{abstract}

\section{INTRODUCTION}

In the last decade, large geomorphological datasets have become increasingly available to the wider public. In the terrestrial environment, extensive Digital Elevation Models (DEMs) are now built from satellite imagery, high-resolution space shuttle radar topography and aerial photography. In the submarine environment, the collection of seafloor swath bathymetry data is now less expensive, and the coverage of seafloor topographic data has increased significantly. The bedforms preserved in these terrestrial and submarine DEMs represent the region's glacial, hydrological and sedimentary history. Drumlins are one such type of glacial bedform which are typically described as streamlined oval-shaped hills with a long axis parallel to the orientation of ice flow and with an upice (stoss) face that is generally steeper than the down-ice (lee) face (Stokes et al., 2011). Initially there was a manual approach to extract drumlins from DEM (Clarke et al., 2004) where drumlins were digitized directly on-screen in a GIS environment by using hill shaded DEMs and other visualization tools (Smith and Clark, 2005; Smith et al., 2006; Smith and Wise, 2007; Spagnolo, 2012). Manual delineation of drumlins from very large datasets is time consuming and a rigorous quality control can be difficult. As an alternative, automated and semi-automated approaches were created to extract drumlins from DEMs with e.g. an object-oriented approach
(Saha et al., 2011), a knowledge-based method (d'OleireOltmanns et al., 2013) and a multiresolution segmentation approach (Eisank et al., 2014). Yu et al. (2015) and Sookhan et.al. (2016) used automated method to extract drumlins from high-resolution Light Detection and Ranging (LiDAR) data. Sărășan et al. (2019) used geomorphons threshold in their automated technique. Yu et al. (2015) used Curvature Based Relief Separation (CBRS) technique for automated drumlin shape and volume estimation using high resolution LiDAR imagery. Sookhan et al. (2016) used the same methodology to perform a volume assessment of the origin of the Wadena drumlin Field, Minnesota, USA. Problem with LiDAR imagery is that they are not available globally and take long time to process because of the high volume.

Like terrestrial, drumlins can also be found at submarine environment. Submarine drumlins or drumlinized terrain have been described by several scholars (Howe et al., 2003; Dowdeswell et al., 2010; Hogan et al., 2010; Batchelor et al., 2011; Robinson \& Dowdeswell, 2011; Streuff, 2013; Ottesen et al., 2006, 2017; Forwick et al., 2014, 2016; Flink et al., 2017b Streuff et al., 2017b; Allaart et al., 2018). Mapping of submarine drumlins most commonly is done from bathymetry from radar altimeters on satellites such as GeoSat and ERS-1. Scholars have analyzed bathymetric data set in GIS environment to map submarine drumlins. So far automated

\footnotetext{
*Corresponding Author
} 
method has not been applied to extract submarine drumlins. In this research, an attempt has been made to extract submarine drumlins using an automated object-oriented classification tool was developed by Saha et al. (2011).

An automated object-oriented classification tool was developed by Saha et al. (2011) to recognize and digitize the terrestrial drumlins in the Chautauqua drumlin field located in NW Pennsylvania and upstate New York (fig.1). The set of rules for object-oriented classification is designed to extract drumlins from a raster dataset using pixel values and contextual information between pixels and image objects (Saha et al., 2011). From the DEM, the topographic variation and its derivatives (values of aspect and slope) were analyzed using eCognition Developer (v.8.7.2). The software performed a multi-resolution segmentation followed by a classification based on a set of rules. Polygons that represent the individual drumlins were then extracted, visualized and statistically compared to those identified via manual digitization. A good agreement between the two methods showed that the automated method is reliable (Saha et al., 2011).

This automated extraction is partly supervised: an initial set of rules is defined to recognize the object (bedform) of interest. Afterwards it can produce consistent and repeatable results. The aim now is to assess whether the method by Saha et al. (2011) is both robust and flexible enough to be easily adjusted and applied to a submarine DEM with a higher resolution of 10 $\mathrm{m}$ and with the challenges of a more complex environment, including the drumlins' (1) more subtle shape, (2) overprinting by other types of bedforms and (3) variable orientation within the field.

If the evaluated tool successfully extracts these submarine drumlins, we demonstrate flexibility in this partly supervised, yet automated method to delineate a wider variety of both glacial and sedimentary bedforms. Automatically delineated objects can also be updated and combined with other thematic data in a Geographical Information System (GIS), which provides a wide range of applications for spatial analyses. A reliable tool to automatically extract geometric information from any object could assist the mapping of, for instance, private gardens in urban areas (Mathieu et al., 2007), neighborhoods with low and high socio-economic status (Stow et al., 2007), soil- and bedrock-dominated landslides (Martin and Franklin, 2005), and urban roof area (Aldred et al., 2011; Saha et al., 2016).

\section{THE STUDY AREAS: TERRESTRIAL AND SUBMARINE DRUMLIN FIELDS}

The terrestrial Chautauqua drumlin field is located south of Lake Erie in Pennsylvania and New York, USA (Fig. 1 - Saha et al., 2011). This field covers more than $2500 \mathrm{~km}^{2}$ and contains over 750 drumlins. A smaller area of $138 \mathrm{~km}^{2}$ within the Chautauqua drumlin field is selected as a test site (Saha et al., 2011).

The submarine drumlin field in the Irish Sea (Fig.2) covers $44.5 \mathrm{~km}^{2}$ and contains over 200 drumlins (Van Landeghem et al., 2009).

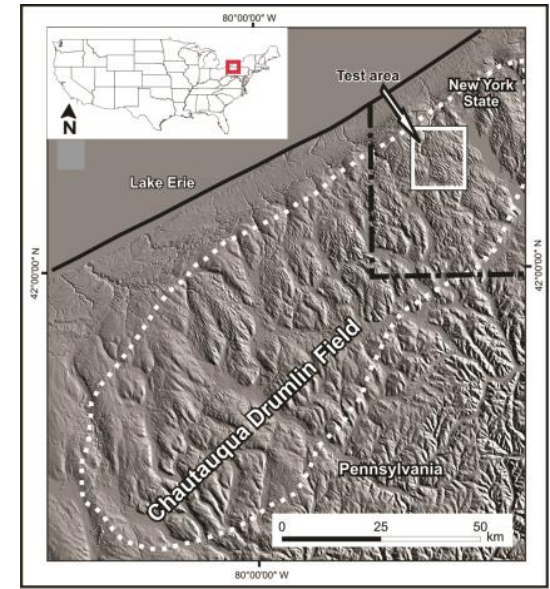

Figure 1. Location of the terrestrial drumlin field in the USA;

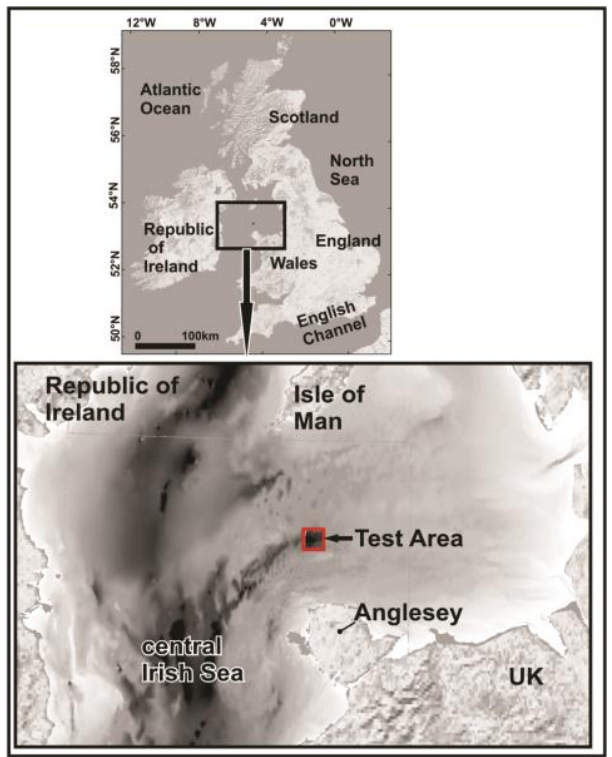

Figure2. Location of the submarine drumlin field in the UK.

The data is projected through UTM $17 \mathrm{~N}$ projection in the NAD 83 geographic coordinate system with the North_American_1983 datum (fig. 3A). In addition to DEMs, Digital Raster Graphics (DRGs) of the topographic maps are used to generate reference maps for comparison. For submarine drumlins, the DEM was generated from the multibeam echosounder data collected in 2006 by the Joint Nature Conservation Committee (JNCC). The submarine DEM is also projected in UTM $30 \mathrm{~N}$ projection in the WGS 1984 geographic coordinate system, vertical datum of Lowest Astronomical Tide (fig. 3B).

The submarine drumlins (70-600 m long) are smaller than the terrestrial drumlins (328-2831 m long), have a wide-ranging elongation ratio, and are often overprinted by other subglacial bedforms like flutes, De Geer moraines, eskers and iceberg keel marks (Van Landeghem et al., 2009). The orientation of the long axes of the submarine drumlins varies from $10^{\circ} \mathrm{N}$ to $100^{\circ} \mathrm{N}$ across the area, whilst the terrestrial drumlins have a more uniform orientation of $150^{\circ} \mathrm{N}$. 


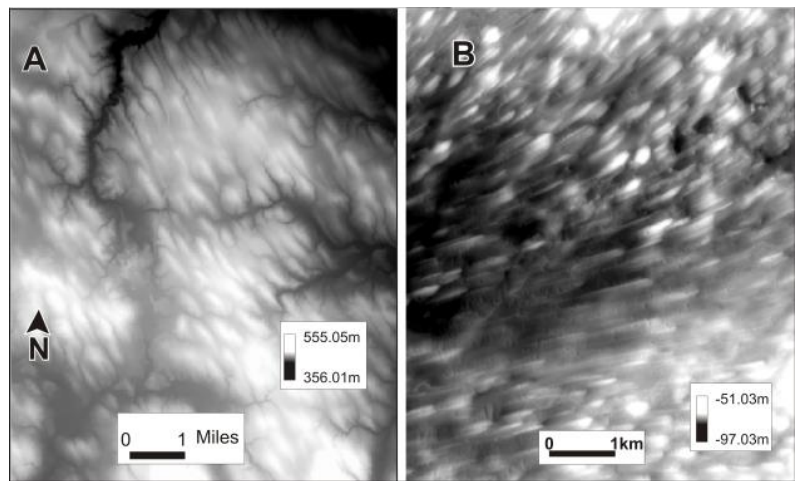

Figure 3. A. Raw DEM data for the terrestrial Test Area (B. Raw DEM for submarine Test Area.

\section{METHODOLOGY}

\subsection{Method for automated extraction of terrestrial drumlins}

The method to build a set of rules to delineate the perimeter of drumlins using object-oriented classification tools is explained in detail in Saha et al. (2011). The process starts with an onscreen digitization of drumlin boundaries of the terrestrial drumlins on Digital Raster Graphics (DRG) of the topographic maps in eCognition Developer. The manually digitized drumlin polygons were overlaid on top of combined layers of elevation, slope and aspect and morphometric parameters were assigned. It was clear from overlay analysis that each terrestrial drumlin has three distinct sections: an east sloping side with slopes between 4 and $10^{\circ}$ and values of aspect between 30 and $100^{\circ}$ (Side I in Fig. 4), a west sloping side with slopes between 4 and $10^{\circ}$ and values of aspect between 200 and $300^{\circ}$ (Side II in Fig.4) and a broad, flat top with slopes between $1-4^{\circ}$ and in no preferred orientation (MidRidge in Fig. 4).



Figure 4. Merged values of elevation (red channel), slope (green channel) and aspect (blue channel) for A. Terrestrial drumlins

Since the terrestrial drumlins have three sections, the process of recognizing individual drumlins starts with the automated extraction of these MidRidges. This is the supervised element in this otherwise automated process. The edge breaks are then detected from the terrestrial DEM using Sobel Edge Detection, and values of slope and aspect are derived and combined into a single thematic layer. From this layer, the crest lines and flanks of the drumlins are found via specific algorithms. After extracting MidRidges, the two lateral sides of the drumlins (Side I and Side II in Fig. 4) were extracted using contextual information. Finally, the three parts were merged to get individual polygons for drumlins. Morphometric data (direction of the long axis, length, width and elongation ratio) for automatically extracted drumlins were collected and saved as a table of attributes for further analysis. The detailed description of automated extraction of terrestrial drumlins is given in Saha et al. (2011), and the summary of this process is given in tabular format (table 1).

\begin{tabular}{|l|l|l|}
\hline Inputs & Algorithm & $\begin{array}{l}\text { Resultant } \\
\text { layer }\end{array}$ \\
\hline $\begin{array}{l}\text { Merge Image 1 } \\
\text { (Elevation+slope+ } \\
\text { aspect layer) }\end{array}$ & $\begin{array}{l}\text { Sobel edge detection } \\
\text { filter to accentuate the } \\
\text { edge effect where there } \\
\text { was a distinct change in } \\
\text { slope and aspect }\end{array}$ & $\begin{array}{l}\text { Thematic } \\
\text { layers } \\
\text { (MidRidge, } \\
\text { Side II) }\end{array}$ \\
\hline $\begin{array}{l}\text { Merge Image 2 } \\
\text { (Merge Image 1+ } \\
\text { Thematic layers) }\end{array}$ & $\begin{array}{l}\text { Multiresolution } \\
\text { segmentation followed by } \\
\text { classification (Criteria: } \\
\text { contextual information \& } \\
\text { Membership function) }\end{array}$ & $\begin{array}{l}\text { Classified } \\
\text { image with } \\
\text { MidRidge, } \\
\text { Side I and } \\
\text { Side II } \\
\text { classes. }\end{array}$ \\
\hline Classified image & $\begin{array}{l}\text { Advance algorithms: } \\
\text { Merge Region, } \\
\text { Morphology }\end{array}$ & $\begin{array}{l}\text { Individual } \\
\text { polygon } \\
\text { for each } \\
\text { drumlin }\end{array}$ \\
\hline
\end{tabular}

Table 1: Set of rules for automated extraction of terrestrial drumlins

These three main steps are now applied to the submarine drumlins and the method from Saha et al. (2011) was thus evaluated. First, the submarine drumlins were also manually digitized on Digital raster Graphics (DRG) of the topographic maps in eCognition Developer. The digitized drumlin boundaries were overlaid on top of combined layers of elevation, slope and aspect to assign morphometric parameters (fig.5).

\subsection{Defining morphometric parameters of drumlins in the terrestrial environment}

The overlay analysis reveals unlike terrestrial drumlins, the marine drumlins generally lack the broad and flat middle ridge. The drumlin tops are mostly sharper, and often the drumlins have flutes overprinted on them (Fig. 5 - Van Landeghem et al., 2009), which changes the morphology of the down-ice facing end of the drumlins, which becomes gradually narrower and thinner. The submarine drumlins have thus two distinct sections instead of three: The north facing sides with slopes between 6 and $20^{\circ}$ and values of aspect between 200 and $360^{\circ}$ (Side A in Fig. 5) and south facing side (Side B in Fig. 5) with slopes between 6 and $20^{\circ}$ and aspect values between 50 and $199^{\circ}$.

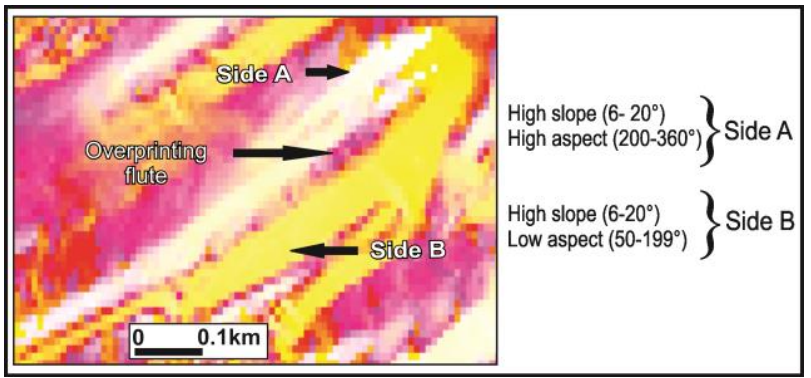

Figure 5. Submarine drumlins in "Merged Image I" (elevationred channel, slope-green channel, aspect- blue channel). 


\subsection{Testing the terrestrial set of rules on submarine drumlins}

The set of rules for automated recognition of terrestrial drumlins was then applied to the $10 \mathrm{~m}$ marine DEM (Fig. 6AD) to recognize the offshore drumlins following the same procedure. Due to morphological differences outlined above, the submarine drumlins were not recognized well using changes in values of aspect as the main discriminator (Fig. 6B). With a poorly recognized flat middle ridge as the spatial connector, the north- and south- facing slopes of the submarine drumlins could not be recognized efficiently either (Fig. 6C), and the final drumlin perimeters did thus not compare well with manually digitized drumlin perimeters (Fig. 6D). The set of rules to recognize the submarine drumlins thus needs to be customized.

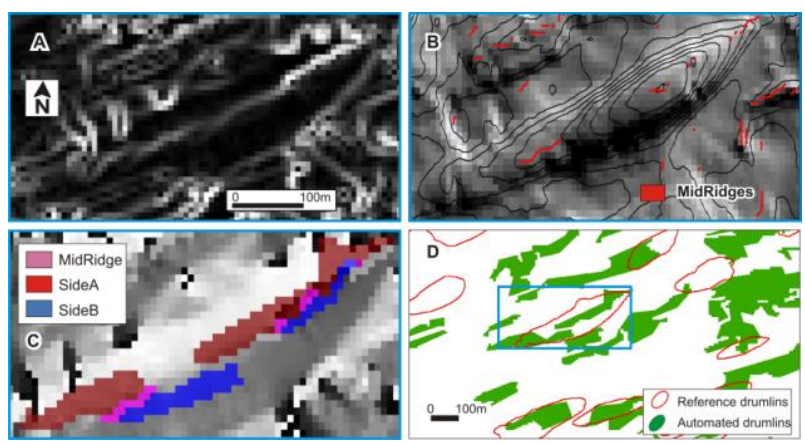

Figure 6. Testing the terrestrial set of rules to automatically extract submarine drumlin perimeters from a DEM, (A) the gradient in values of aspect, amplified via the Sobel edge detection filter (B) the terrestrial set of rules fails to extract the top middle ridges, $(\mathrm{C})$ the unsatisfactory extraction of the three parts of the submarine drumlin, and (D) automatically extracted drumlin polygons do not compare well with the manually digitized drumlin polygons.

\subsection{Automated recognition of submarine drumlins via a different set of rules}

In the gentle sloping offshore environment, a Canny Edge Detector filter was applied instead of the Sobel Edge detection filter to accentuate the edge effect around the drumlin perimeter. This filter uses a Gaussian convolution technique to smoothen the image and then a non-maximal suppression process is applied to identify pixels which show distinct changes compared to the two adjacent pixels. Those pixels are identified as edge candidates and appear bright in the output layer (Liu \& Jezek, 2004). The outcome of the Edge filter process is referred to as the "Elevation Edge layer" in the flow chart in Fig. 7. This layer was then segmented using the eCognition developer's Contrast Split segmentation algorithm which merged the pixels with a higher grey value into brighter objects (Fig. 7A). Brighter objects were classified (fig.7B) and exported to a shape file, named "Potential Drumlin Perimeter.shp" (see flow chart in Fig. 7).

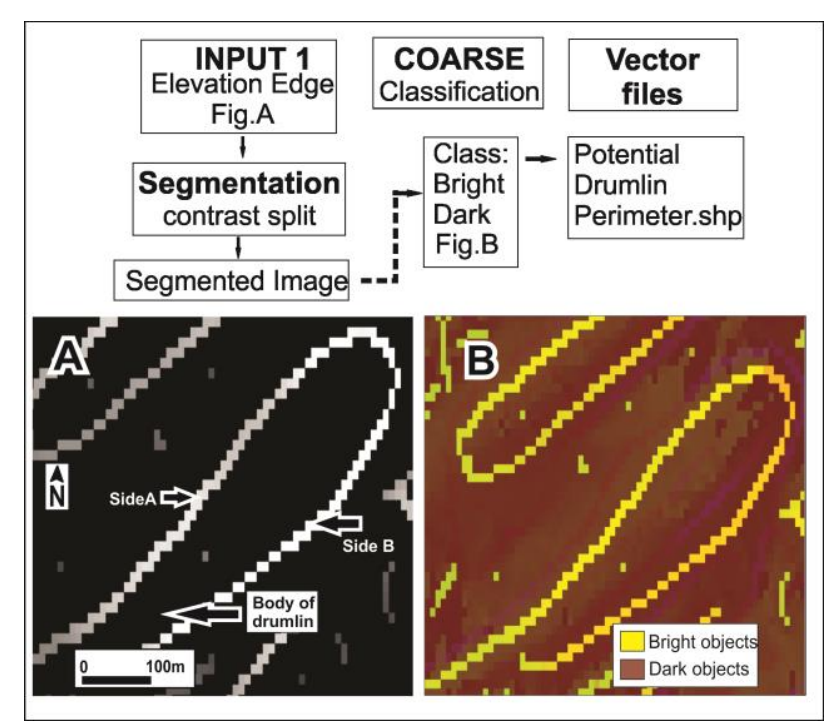

Figure 7. Pre-processing of data for automated extraction of submarine drumlins: A. Application of Canny Edge Detector filter to a layer with very high pixel values where there was an edge between two objects, B. classified image with Potential Drumlin Perimeter class.

A "Merged Image 2" was generated by merging "Merge Image 1" (Fig. 8A) and the elevation edge. The slope gradient was then analyzed via the Multiresolution Segmentation (MS) algorithm (Fig. 8B). MS segmentation in eCognition Developer merges the pixels based on homogeneity criteria like spectral or shape homogeneity. Shape can further be influenced by defining a scale parameter. A large scale setting results in larger image objects while a small-scale setting results in smaller objects (eCognition Developer, 2012). In this case, maximum weightage was given to shape and scale was set to high to ensure that the DEM was segmented into shapes that matched the predefined drumlins boundary in the vector layer. To distinguish drumlin boundaries from other seafloor features, threshold values for aspect $\left(200-360^{\circ}\right)$ for the north-facing side and $\left(50-199^{\circ}\right)$ for the south-facing side, orientation $(10-$ $\left.100^{\circ} \mathrm{N}\right)$ and length $(>100 \mathrm{~m})$ were used in the classification process, and the boundaries of both drumlin sides were thus extracted (Fig. 8B). For the automated recognition of the drumlin bedforms, named "Body of drumlin" in the flow chart in Fig. 8, the spatial relationship between a potential bedform and the drumlin boundaries "Side A" and "Side B" was applied (Fig. 8C). After the automated extraction of these three drumlin parts, the objects were merged, and any gaps were filled (Fig. 8D). Morphometrics were then measured for each drumlin polygon using the routine measurement tools in eCognition Developer. 


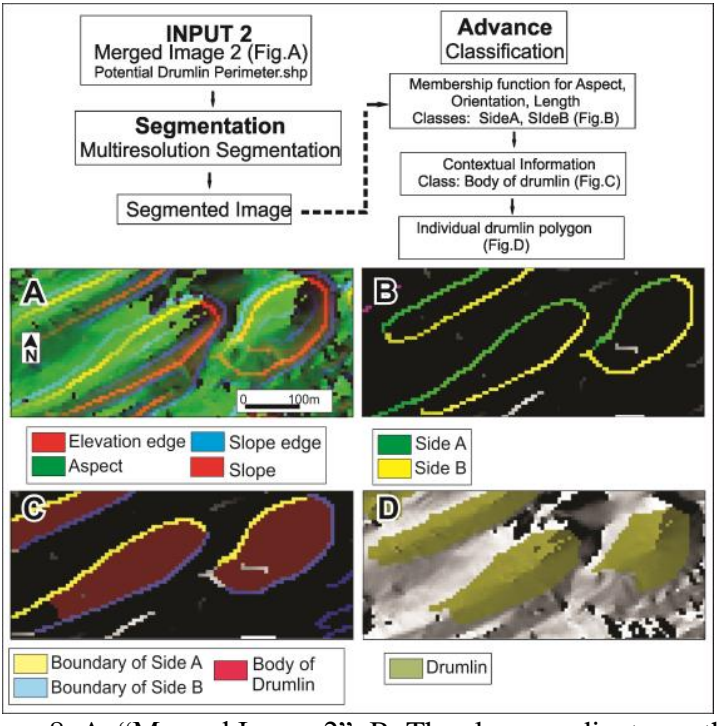

Figure 8. A. "Merged Image 2"; B. The slope gradient was then analyzed via the MS Segmentation, C. Classified image with 3 classes, D. Individual polygon for each drumlin.

\section{EVALUATING THE ORIGINAL AND THE REVISED DRUMLIN RECOGNITION METHOD}

Evaluation of the original and revised drumlin recognition method was done through both visual and quantitative assessment.

\subsection{Visual comparison}

For this purpose, reference maps were produced using Merged Image 1 (combined image of elevation, slope and aspect), along with the DRG of the topographic map. Following the changes in slope and aspect, the drumlin boundaries were identified and digitized on-screen using eCognition developer software. A total of 129 and 223 drumlin perimeters were digitized manually in the terrestrial and the submarine datasets respectively and saved in vector format. The two vector files containing manually digitized drumlins and automatically extracted drumlins were overlaid and visually compared (Fig. 9).

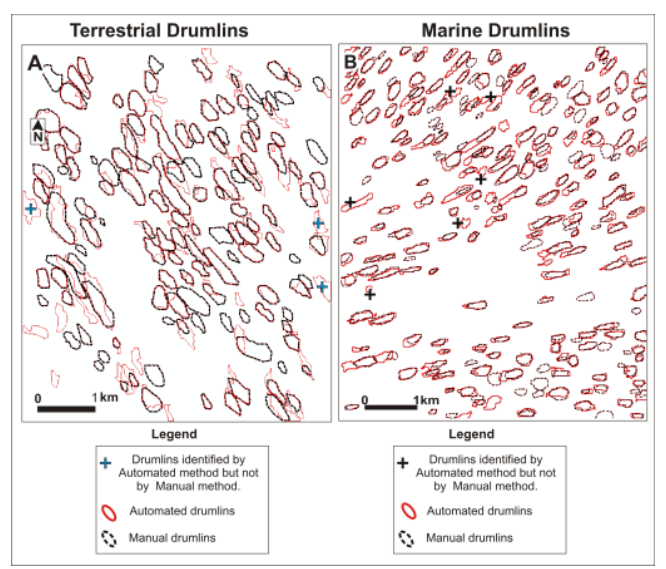

Figure 9. Visual comparison between automatically and manually extracted drumlins, both in A. the terrestrial test environment (see Saha et al. 2011) and B. the submarine test environment.
Overall, the method of object recognition generated satisfactory results, visualized in Fig. 9. For terrestrial drumlins, the original automated method (Saha et al. 2011) identified $86 \%$ of manually digitized drumlins (Fig. 9A). In submarine environment, the automated method identified $81 \%$ of the manually digitized drumlins (Fig. 9B). The revised automated extraction method performed well where the drumlins are subdued and overprinted. Other elongated bedforms (like sediment waves) have not been falsely identified as drumlins (Fig. 10A) and some of the heavily overprinted drumlins were delineated automatically where the manual digitization failed (Fig. 10A). The automated method has particularly failed to identify those drumlins that are extremely shallow (thus lacking significant slopes) and drumlins across interrupted data coverage (Fig. 10A), whilst it delineated some seafloor depressions incorrectly as drumlins (Fig. 10B).

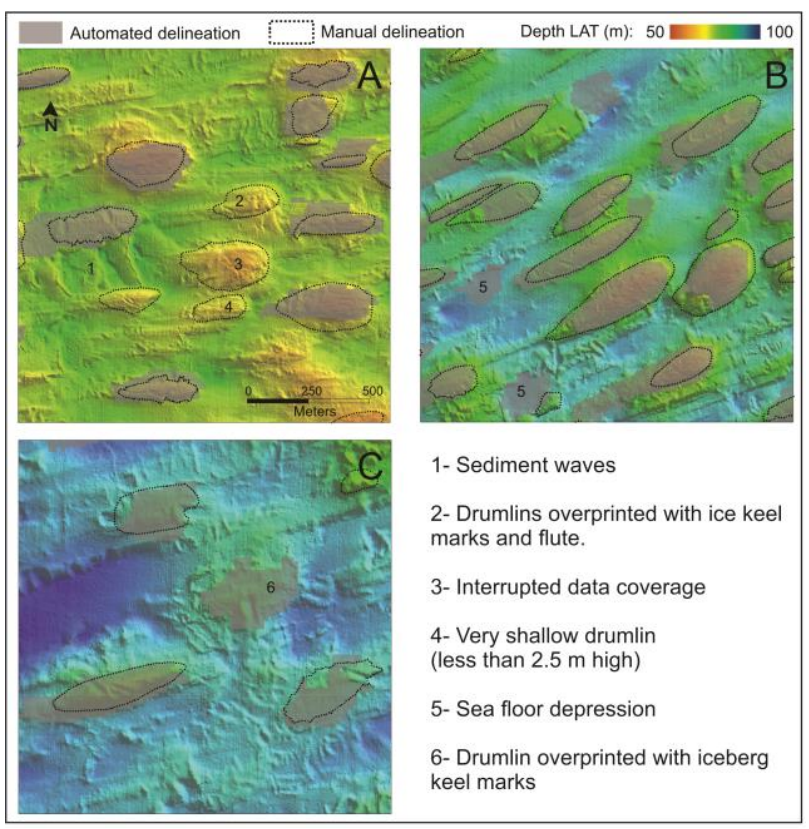

Figure 10. Visual comparison between drumlins extracted in two different method in the submarine environment zoomed in to 3 areas where there is a mismatch between the two methods.

\subsection{Quantitative comparison}

In order to extract statistics for the manually mapped drumlins, the vector layer of submarine drumlin polygons (see section 4.1.) was used to segment "Merge Image 1" using the MS Segmentation process. As mentioned in section 4.3, the shape parameter was emphasized in the segmentation process to extract drumlin polygons from the DEM using a vector layer as cookie-cutter. The identified objects were classified as drumlins and, as we did for terrestrial drumlins, the morphometric data were collected for submarine drumlins and saved as a table of attributes.

To quantify the differences in outcomes between automated and manual drumlin recognition in both environments, the morphometric data were analyzed and compared (Fig. 11). The automated method better identifies long, and wide terrestrial drumlins compared to the manual method, which was already observed and explained in Saha et al. (2011. Here we notice that the same effect is apparent in the marine environment (Fig. 12). 


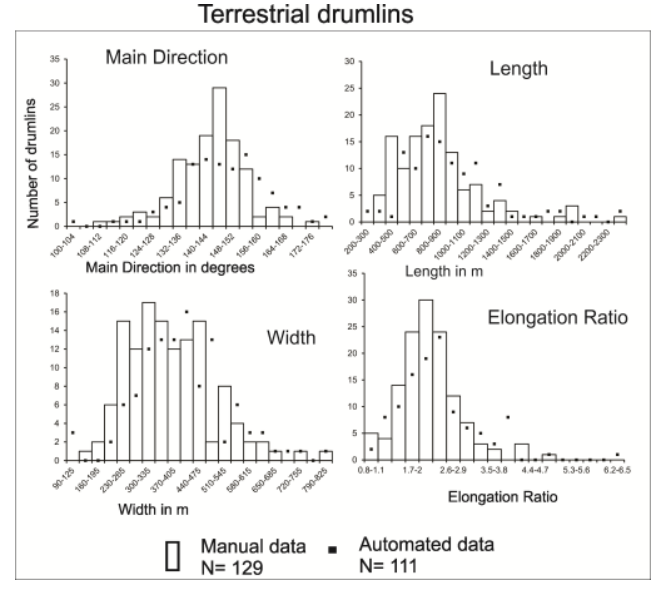

Figure 11. Comparing morphometric parameters of the automatically and manually delineated drumlins in the terrestrial environment (Saha et al. 2011).

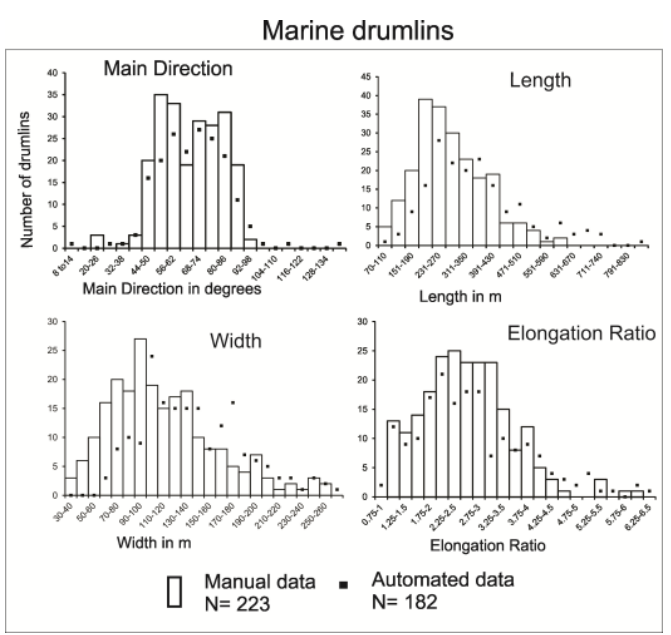

Figure 12. Comparing morphometric parameters of the automatically and manually delineated drumlins in the marine environment.

\section{CONCLUSION AND WIDER IMPLICATIONS}

This paper, for the first time, compares the outcomes of an automated method to delineate drumlins using DEMs from two different environments: a terrestrial and a marine setting. The object-oriented classification tool under evaluation was developed by Saha et al. (2011) using eCognition Developer and based on a set of rules.

We show in this work that an expertise-based modification of this tool is necessary to successfully recognize the same type of bedform in different conditions of formation and/or preservation. Because the terrestrial drumlins of the Chautauqua Drumlin field are located on highly incised topography, the variations of slope and elevation across the drumlins play a relatively smaller role in recognizing the objects compared to the variations of aspect across the drumlins. The set of rules for automated object recognition used for the terrestrial drumlins thus mainly focuses on variations in aspect. In contrast, the submarine drumlins off north Wales are more subtle, overprinted and show a wider variety in orientation. As a result, the automated extraction of these drumlins is based more dominantly on the recognition of variation in elevation. With a supervised approach in modifying the tool to its environment, we find that the tool is reliable and flexible.

This automated method of object delineation is quicker than manual techniques and it reduces the inherently subjective nature of manual object recognition and digitization. It has the potential to be applied to any bedform with characteristic geometric features and it has the capability to automatically classify the topography of very large-scale datasets, such as global Shuttle Radar Topography Mission (SRTM) data.

\section{REFERENCES}

Aldred, D. W., 2011. A Method for Obtaining and Applying Classification Parameters in Object-Based Urban Rooftop Extraction from VHR Multispectral Images. International Journal of Remote Sensing, 32, 2811-2823.

Allaart, L., Friis, N., Ingólfsson, Ó., Håkansson, L., Noormets, R., Farnsworth, W. R., ... \& Schomacker, A., 2018. Drumlins in the Nordenskiöldbreen forefield, Svalbard. GFF, 140(2), 170188.

Anders, N. S., Seijmonsbergen, A. C., \& Bouten, W., 2011. Segmentation optimization and stratified object-based analysis for semi-automated geomorphological mapping. Remote Sensing of Environment, 115, 2976-2985.

Batchelor, C., Dowdeswell, J. \& Hogan, K., 2011: Late Quaternary ice flow and sediment delivery through Hinlopen Trough, Northern Svalbard margin: submarine landforms and depositional fan. Marine Geology, 284, 13-27.

Clark, C. D., Evans, D. J. A., Khatwa, A., Bradwell, T., Jordon, C. J., Marsh, S. H., Mitchell, W. A., \& Bateman, M. D., 2004. Map and GIS database of glacial landforms and features related to the last British Ice Sheet. Boreas, 33, 359-375.

d'Oleire-Oltmanns, S., Eisank, C., Dragut, L., \& Blaschke, T., 2013. An object-based workflow to extract landforms at multiple scales from two distinct data types. IEEE Geoscience and Remote Sensing Letters, 10, 947-951.

Dowdeswell, J.A., Hogan, K., Evans, J., Noormets, R., Cofaigh, C.Ó. \& Ottesen, D., 2010: Past ice-sheet flow east of Svalbard inferred from streamlined subglacial landforms. Geology 38, 163-166.

eCognition Developer Userguide, 2012. Version 8.7.2. Trimble Germany GmbH, Trapentreustr.1.D-80339 Muchen, Germany. pp. 255 .

Eisank, C., Dragut, L., \& Blaschke, T., 2011. A generic procedure for semantics-oriented landform classification using object-based image analysis. Paper presented at the Geomorphometry 2011, Redlands, CA. Retrieved from http://www.geomorphometry.org/system/files/Eisank2011geom orphometry.pdf.

Flink, A.E. \& Noormets, R., 2017b: Submarine glacial landforms and sedimentary environments in Vaigattbogen, northeastern Spitsbergen. Marine Geology, 402, 244-263. 
Forwick, M., Dowdeswell, J., Laberg, J. \& Ottesen, D., 2016: Glacial landform assemblages in Spitsbergen fjords from the last full-glacial, deglaciation and the late Holocene. Geological Society, London, Memoirs 46, 147-150.

Forwick, M., Sverre Laberg, J. \& Husum, K., 2014: Bathymetry and seismic stratigraphy in St. Jonsfjorden, Spitsbergen. EGU General Assembly Conference Abstracts.

Hogan, K., Dowdeswell, J., Noormets, R., Evans, J., Cofaigh, C.Ó. \& Jakobsson, M., 2010: Submarine landforms and icesheet flow in the Kvitøya Trough, northwestern Barents Sea. Quaternary Science Reviews 29, 3545-3562.

Howe, J.A., Moreton, S.G., Morri, C. \& Morris, P., 2003: Multibeam bathymetry and the depositional environments of Kongsfjorden and Krossfjorden, western Spitsbergen, Svalbard. Polar Research 22, 301-316.

PCI Geomatica userguide, 2007. Version 10.1. PCI Geomatics, 50 West Wilmot St., Suite 200, Richmond Hill on Canada L4B 1 M5. pp. 413.

Jorge, M. G., \& Brennand, T. A., 2017. Semi-automated extraction of longitudinal subglacial bedforms from digital terrain models-Two new methods. Geomorphology, 288, 148163.

Liu, H., \& Jezek, K. C., 2004. Automated extraction of coastline from satellite imagery by integrating Canny edge detection and locally adaptive thresholding methods. International Journal of Remote Sensing, 25(5), 937-958.

Martin, Y. E., \& Franklin, S. E., 2005. Classification of soiland bedrock-dominated landslides in British Columbia using segmentation of satellite imagery and DEM data. International Journal of Remote Sensing, 26 (7), 1505-1509.

Mathieu, R., Freeman, C., \& Aryala, J., 2007. Mapping private gardens in urban areas using object-oriented techniques and very high-resolution satellite imagery. Landscape and Urban Planning, 81 (3), 179-192.

Ottesen, D. \& Dowdeswell, J., 2006: Assemblages of submarine landforms produced by tidewater glaciers in Svalbard. Journal of Geophysical Research: Earth Surface 111, 16.

Ottesen, D., Dowdeswell, J.A., Bellec, V. \& Bjarnadóttir, L., 2017: The geomorphic imprint of glacier surges into openmarine waters: examples from eastern Svalbard. Marine Geology, 392, 1-29.

Pelletier, J. D., 2008. Quantitative Modeling of Earth Surface Processes. Cambridge University Press, Cambridge, 304 pp.

Saha, K., Wells, N. A., \& Munro-Stasiuk, M., 2011. An objectoriented approach to automated landform mapping: A case study of drumlins. Computers \& Geosciences, 37, 1324-1336.

Robinson, P. \& Dowdeswell, J.A., 2011: Submarine landforms and the behavior of a surging ice cap since the last glacial maximum: the openmarine setting of eastern Austfonna, Svalbard. Marine Geology, 286, 82-94.
Saha, K., \& Mandal, N. R., 2016. Estimating Solar PV Potential for Sustainable Energy Planning in Tier-II Cities of India: Case of Bhopal City. Current Urban Studies, 4(03), 356.

Sărășan, A., Józsa, E., Ardelean, A. C., \& Drăguț, L., 2019. Sensitivity of geomorphons to mapping specific landforms from a digital elevation model: A case study of drumlins. Area, 51(2), 257-267.

Smith, M. J., \& Clark, C. D., 2005. Methods for the visualization of digital elevation models for landform mapping. Earth Surface Processes and Landforms, 30, 885-900.

Smith, M. J., Rose, J., \& Booth, S., 2006. Geomorphological mapping of glacial landforms from remotely sensed data: an evaluation of the principal data sources and an assessment of their quality. Geomorphology, 76, 148-165.

Smith, M. J., \& Wise, S. M., 2007. Mapping glacial lineaments from satellite imagery:an assessment of problems and development of best procedure. International Journal of Applied Earth Observation and Geoinformation, 9, 65-78.

Sookhan, S., Eyles, N., \& Putkinen, N., 2016. LiDAR-based volume assessment of the origin of the Wadena drumlin field, Minnesota, USA. Sedimentary Geology, 338, 72-83.

Spagnolo, M., Clark, C. D., \& Hughes, A. L. C., 2012. Drumlin relief. Geomorphology 153-154, 179-191.

Streuff, K.T., 2013: Landform assemblages in inner Kongsfjorden, Svalbard: evidence of recent glacial (surge) activity. Universitetet i Troms $\varnothing$, Troms $\varnothing$.

Streuff, K., Cofaigh, C.Ó., Noormets, R. \& Lloyd, J., 2017b: Submarine Landforms and Glacimarine Sedimentary Processes in Lomfjorden, East Spitsbergen. Marine Geology, 390, 51-71.

Stokes, C. R., Spagnolo, M., \& Clark, C. D., 2011. The composition and internal structure of drumlins: Complexity, commonality, and implications for a unifying theory of their formation. Earth-Science Reviews, 107, 398-422.

Stow, D., Lopez, A., Lippitt, C., \& Hinton, S., 2007. Object based classification of residential land use within Accra, Ghana based on QuickBird satellite data. International Journal of Remote Sensing, 28 (22), 5167-5173.

Todd, B. J., Valentine, P. C., Longva, O., \& Shaw, J., 2007. Glacial landforms on German Bank, Scotian Shelf: Evidence for Late Wisconsinan ice-sheet dynamics and implications for the formation of De Geer moraines. Boreas, 36, 148-169.

Van Landeghem, K. J. J., Wheeler, A. J., \& Mitchel, N. C., 2009. Seafloor evidence for palaeo-ice streaming and calving of the grounded Irish Sea Ice Stream: Implications for the interpretation of its final deglaciation phase. Boreas, 38, 119131.

Yu, P., Eyles, N., \& Sookhan, S., 2015. Automated drumlin shape and volume estimation using high resolution LiDAR imagery (Curvature Based Relief Separation): A test from the Wadena Drumlin Field, Minnesota. Geomorphology, 246, 589 601. 